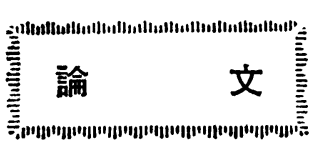

\title{
蛍光ランプヘの応用を目指した低圧水銀-アルゴン 放電陽光柱のシミュレーションモデル
}

\author{
正会員 和 迩 浩 -*
}

\section{A Simulation Model for the Hg-Ar Positive Column applicable to the Fluorescent Lamp Discharges}

Koichi Wani (Member)

(Research Laboratory, Matsushita Electronics Corporation)

\begin{abstract}
A simulation model which describes the time-dependent behavior of the positive column of a low-pressure mercury-rare gas discharge was developed.

Excitation processes of $\mathrm{Hg} 6{ }^{1} \mathrm{P}_{1}$ level was analysed by comparing afterglow characteristics of the observed discharge with those of an elementary model. A stepwise excitations from $\mathrm{Hg} 6{ }^{3} \mathrm{P}$ levels were shown to be dominant processes, and were introduced into the model.

From the experimental analyses, the electron energy distribution function was proved to be non-Maxwellian in the discharge under consideration. In the model calculation, the distribution function was approximated with a two-temperature representation.

Relative intensities of the $\mathrm{Hg} 254 \mathrm{~nm}$ and $185 \mathrm{~nm}$ radiations from a $24 \mathrm{~mm}$ diameter tube were measured for coldest spot temperatures between 20 and $60^{\circ} \mathrm{C}$. There was a good agreement between the measurement and the calculation for the 254 $\mathrm{nm}$ radiation. The calculated $185 \mathrm{~nm}$ radiation power was found to be larger than the observed results at the low mercury pressure end.
\end{abstract}

\section{1. ま え がき}

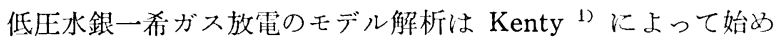
られた。 その後, Waymouth ${ }^{2)}$, Cayless ${ }^{3)}$, Vriens ${ }^{4)}$ らが改良 を進め, 定常放電に括いては実測值をかなりよく説明できるモデ ルを得ている. 時間的に変化する放電を取り扱った例は Polman ら5) に代表される。

解析モデルを改良するには, プラズマバラメータを実測して比 較・検討することが重要なプロセスとなる. 低圧水銀 - 希ガス放

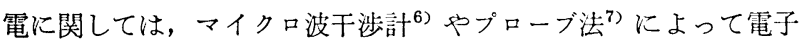
密度が，マイクロ波放射温度計(6)やプローブ法78) によって電子温 度が，吸収法6)日) で水銀の励起状態密度がそれぞれ測定され，解 析の基礎データとなってきた. 一方，水銀の共鳴線の相対強度 は, 比較的簡単に测定できるが，定常放電で水銀の励起過程の解 析に役立てた例は少ない。

われわれは，まずアフターグローヤの共鳴線相対強度の減衰特 性を, 実験と放電陽光柱の時間的変化を記述する理論との両面か

\footnotetext{
* 松下䉓子工業晽電子研究所 Research laboratory, Matsushita Electronics Corporation
}

ら解析した，乙の結果，水銀原子の階段状励起を定量的に評価し て，解析モデルにフィードバックすることに成功した．次に，電 子ェネルギー分布について検討し，プラズマパラメータの中でも 比較的簡単に测定できる, 陽光柱の電位傾度を入力パラメータと して追加するだけで, 非マクスウェル分布を近似的に導入できる 放電シミュレーションモデルに到達した. 最後に, 水銀共鳴線の 相対放射強度を测定し, 本研究のシミュレーションモデルによっ てその挙動をよく説明できることを示した。

\section{2. 解析モデル ${ }^{10) 111}$}

\section{1 基 本 仮 定}

放電中のプラズマパラメータの時間的変化は速度方程式拈よび エネルギー平衡式の連立方程式で表せる．これを解いて放電陽光 柱の中心軸上の水銀励起状態密度 $n_{j}$, 電子密度 $n_{e}$ 括よび電子 温度 $T_{e}$ を求めた。

図 1 にモデル式に導入した水銀の原子的過程を示す. バッフ ァガス（アルゴン）と電子の非弾性衝突は無視できる. 监光ラン プ様放電に拁いて，電子の消隇過程として両極性払散だけが支配 的で, 体積再結合は無視できる. 本研究の対象となる, 電流停止 後 0 数 $10 \mu \mathrm{s}$ のアフターグロー中においても, 電:子温度はそれ ほど低下せず，休積再結合を無視できる程度であった。 


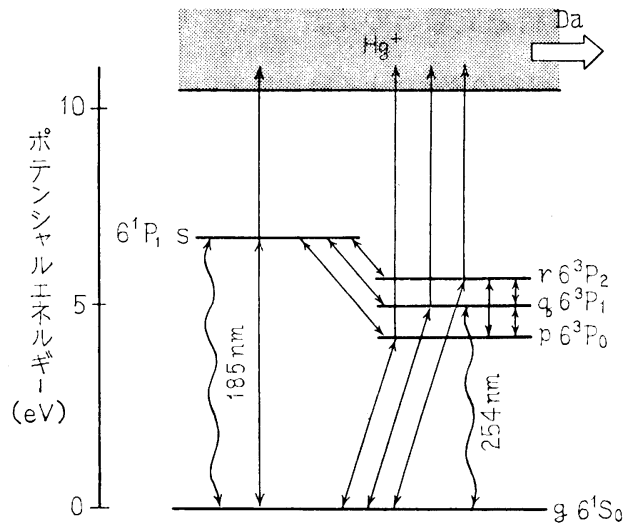

図 1 モデルに鼻人した水銀のエネルギー準位

粒子密度, 温度の放電管径力向の分布については, 文献による 理論あるいは実测值に基づき，以下のように仮定した。宦于温度

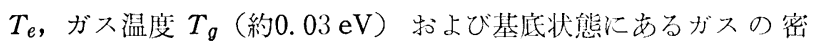
度 $n_{g}$ は放電管径方向に一様であるとした ${ }^{3)}$. 電子の密度分仍は 零次のベッ七ル関数で近似できる7). 水銀励起準位の密度はトラ ッピングされた共鳴放射の基底関数 $\phi_{0}$ で表せることが理論的に 示されるが(2), 実測データ ${ }^{132}$ との比較から零次のべッセル関数で 近似した. 従がって, 電子密度拈よび励起状態密度の放電管軸上 の值は $n_{j}=\overline{n_{j}} / 0.43$ となる。 ここで， $\overline{n_{j}}$ は平均密度である. 電 子ェネルギー分布については当初, マクスウェル分布を採用した.

\section{2 モ゙゙ル式}

水銀励起準位の密度 $n_{j}$ の時間的変化を表す速度力程式は以下 のように書ける.

$$
\frac{d}{d t} n_{j}(t)=\sum_{i} C_{i j} n_{i} n_{e}-\sum_{i} C_{j i} n_{j} n_{e}-\sum_{i} S_{i} n_{i} n_{e}-g_{j} A_{j g} n_{j}
$$

$$
(i=g, p, q, r, s ; j=p, q, r, s,)
$$

ここで, 添字 $g$ は基底状態を, $p, q, r, s$ は励起状態を, $e$ は電 子を意味する. また $C_{i j}$ は $i$-準位から $j$-準位への励起速度係 数, $S_{j}$ は $j$-準位からの電離速度係数, $A_{i g}$ は $i$-準位から基底 状態への放射遷移の確率（準安定準位 $p, r$ では零）である. $g_{j}$ は共鳴線の閉じ込め係数 (escape factor) であり, Holstein の 式 ${ }^{12)}$ とって計算した. $254 \mathrm{~nm}$ 共鳴線は水銀原子の同位体シフ トがあるため, ほぼ等しい強度を持つ 5 本の微細スペクトルに分 かれる.この効果を考虑して, Holstein の式に用いる吸収係数 を単一スペクトルの場合の $1 / 5$ として計算した. $185 \mathrm{~nm}$ 線の微 細構造についてはデータが見当たらないが，両共鳴線の上位準位 の全角運動量量子数が等しいことから, $254 \mathrm{~nm}$ と同様の 微細構 造を持つと仮定し, 吸収係数を $1 / 5$ として計算した. アフターグ ロ一中の減衰曲線を計算すると, 初期の減衰の时定数が実測と一 致するので, この仮定は妥当と考えてよい。

電子密度 $n_{e}$ の時間的変化は, 両極性昖散係数 $D_{a}$ 吕用いて励 起状態の場合と同㥞の速度方程式

$$
\frac{d}{d t} n_{e}(t)=\sum_{i} S_{i} n_{i} n_{e}-D_{e} \nabla^{2} n_{e}(r)
$$

で表せる. $\nabla^{2} n_{e}(r)$ は電子密度の径方向分布の 2 階徽分を示し, 電子密度の分布を零次のベッセル関数で裴した場合, 放電管の軸 上 $(\boldsymbol{r}=0)$ で5.784 $n_{e} / R^{2}$ となる. ここで $R$ は放電管の半径 $(=d / 2)$ である.

電子の平均エネルギーの平衡式は次のように書ける.

$$
\begin{aligned}
& \frac{3}{2} k \frac{d}{d t} T_{e}(t)=\frac{J^{2}}{n_{e}^{2} e \mu_{e}}-\sum_{i}\left(\frac{5}{2} k T_{e}+u_{i}\right) S_{i} n_{i} \\
& \quad-\nu_{e} \frac{3 m_{e}}{m_{g}} k\left(T_{e}-T_{g}\right)+\sum_{i} \sum_{j} \Delta u_{i j} C_{i j} n_{i} \cdots \cdots \cdots(3)
\end{aligned}
$$

ここで, $k$ はボルツマン定数, $J$ は放電管軸上の電流密度, $e$ は素 電荷, $\mu_{e}$ は電子の移動度, $\nu_{e}$ は電子之中性原子の衝突頻度, $m_{e}$, $m_{g}$ はそれぞれ電子，中性原子の質量である，右边第 1 項は電界 による電子の加速を，第 2 項，符 3 項はそれぞれ電離衝突（しき い值 $u_{i}$ ), 弾性衝突による損失を, 第 4 項は励起, 脱励起（しき い值 $\Delta u_{i j}$ ）によるェネルギーの移動を示す.

電子ェネルギー分布をマクスウェル分布とした場合, 速度係数 $C_{i j}$, 衝突頻度 $\nu_{e}$, 両極性払散係数 $D_{a}$ は電子温度 $T_{e}$ だけの関 数になる. また, 移動度 $\mu_{e}$ は $\nu_{e}$ の関数であるので, 結局, 式 (1) (3)は 1 階 6 元の連立微分方程式となる. 各過程の衝突断面積 のデータ, 出典は参考文献(10)に示した.

\section{3 放電パラメータの計算式}

放電管単位長さ当たりの共鳴線の放射パワー $P_{j}$ は, 共鳴準位 の密度 $\bar{n}_{j}(j=q, s)$ を用いて次式から計算できる.

$$
P_{j}=\overline{n_{j}} g_{j} A_{j g}\left(h c / \lambda_{j}\right) \pi R^{2} \ldots
$$

ここで, $h$ はプランクの定数, $c$ は真空中の光速, $\lambda_{j}$ は共鳴線の 波長である.

また, 陽光性の電位傾度 $E$ は,

$$
E=J /\left(n_{e} e \mu_{e}\right)
$$

の関係から得られるので, 共鳴線の放射効率 $\eta_{j}$ は次式のように なる。

$$
\eta_{j}=P_{j} /(I E)
$$

ここで，Iは放電電流 $\left(=0.43 \pi R^{2} J\right)$ である.

\section{3. 共鳴線の減衰特性の観測 ${ }^{10)}{ }^{14)}$}

\section{1 実 験 装 置}

図 2 に実験装置のブロック図を示す. $333 \mathrm{~Pa}$ (2.5 Torr)のア ルゴンを封入した内径 $18.5,23.5,28.5 \mathrm{~mm}$ の 3 種の石英 製放 電管（電極間長 $360 \mathrm{~mm}$ ）を，休止期間，繰り返し周波数が可変 の方形波電源で点灯した. 放電電流 $I$ は定常値を $0.3,0.4,0.5$ $\mathrm{A}$ 之変えて, 電流停止後の共鳴線の減衰を観测した。放電電流の 立下がり時間は0. $5 \mu \mathrm{s}$ 以内であった.

電流を流す期問 $t_{\mathrm{on}}$ は各電流值で, $100 \mu \mathrm{S}$ 一定にした. 一方, 電流の停止期間 $t_{\mathrm{off}}$ は電流值によって変化させ, 平均投入電力を
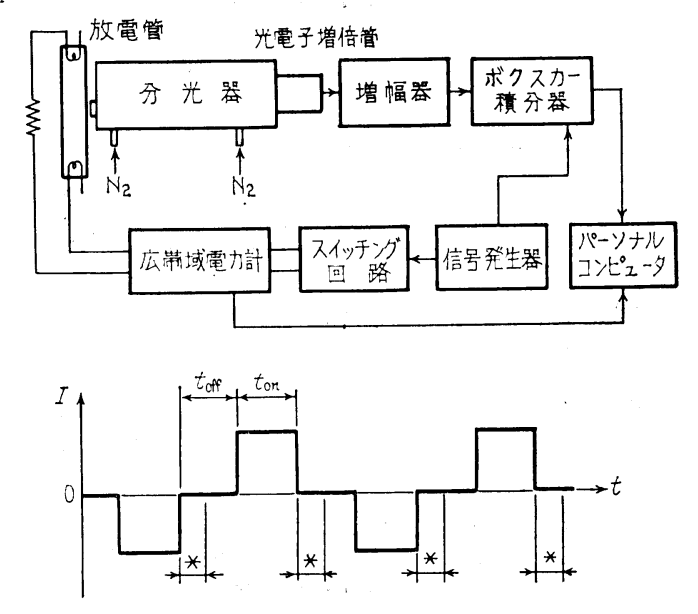

图 2 実験装置 (*はアフターグローの钼測期間を示す) 
制御することによって最冷点温度 $T_{w}$ （管中央下面で測定）が 40 $\pm 0.5^{\circ} \mathrm{C}$ の範囲に收まるようにした. その結果, 放電電流 $0.3 \sim$ $0.5 \mathrm{~A}$ に対して, 点灯周波数は $1.3 \sim 1.0 \mathrm{kHz}$ の間で変化した.

共鳴線放射の相対強度は, 内部を毎分約 $100 \mathrm{~cm}^{3}$ の窒素で連 続 的に膡換したモノクロメータ(Jobin-Yvon DH-20)の入射スリッ トに放電管を近接して観測した.これによって，空気中と比べて 数十倍の強度で $185 \mathrm{~nm}$ 共鳴線を钼測できた. 光の信号は Cs-Te 光電陰極の光電子增倍管（浜松ホトニクス R $166 \mathrm{UH}$ ）で検出し， ボクスカー積分器で 500〜1000 サイクルの波形を蓄積することに よって $\mathrm{S} / \mathrm{N}$ 比を向上した減衰曲線を得た. 测定系の时間分解能 は約 $0.5 \mu s$ であった。

\section{2 減衰曲線の観測結果}

図 3 K, 内径 $23.5 \mathrm{~mm}$ の放電管に拈ける，水銀 $254 \mathrm{~nm}$ 打よ び185 nm 共鳴線のアフターグロー中の相対強度の時問的变化を 示す．減衰曲線は 2 つの領域に分かれる．最初の減衰の時定数は $254 \mathrm{~nm}$ で約 $7.5 \mu \mathrm{s}, 185 \mathrm{~nm}$ で約 $3.0 \mu \mathrm{s}$ で, 放電電流に依存 し

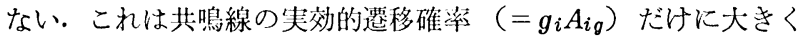
支配されているためである. 電流停止後 $3 \mu \mathrm{s}$ 以降, 緩やかに減 衰する電子温度 $T_{e}$ （図 4）によって共鳴準位への励起が続き, 時定数は大きくなる.アフターグロー中の $T_{e}$ の緩やかな減哀は 水銀の準安定原子の脱励起,

$$
\mathrm{Hg}\left(6{ }^{3} \mathrm{P}_{0,2}\right)+\boldsymbol{e} \rightarrow \mathrm{Hg}\left(6{ }^{1} \mathrm{~S}_{0}\right)+(\boldsymbol{e}+\Delta u)
$$

によって，電子にェネルギーが与えられるためと説明できる ${ }^{6)}$.

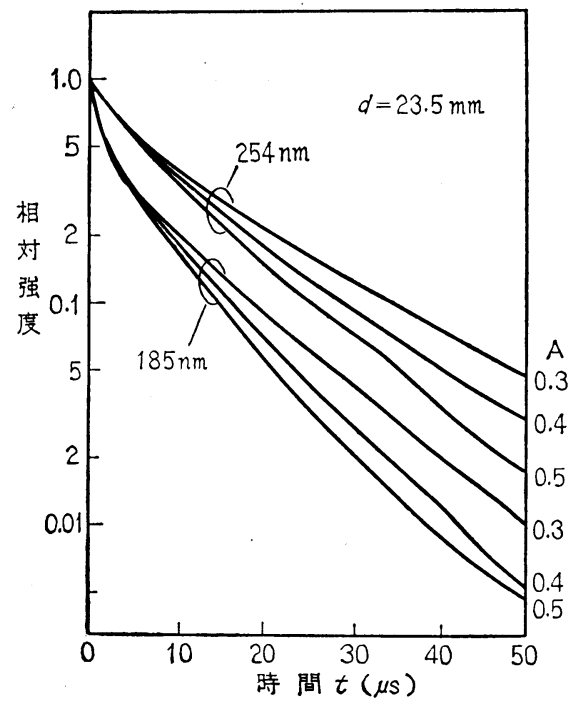

図 3 共鸣線の減衰曲線（测定結果）

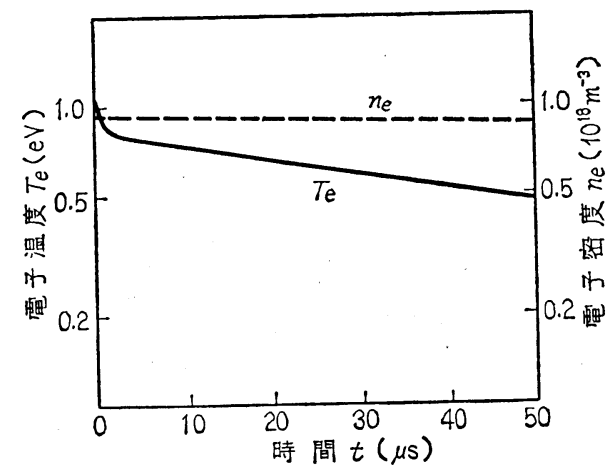

図 4 電子温度, 密度の減衰曲線（計算結果）

\section{4. 数值解析と実験との比較 - 階段状励起の導入 ${ }^{10) 11)}$}

\section{1 階段状励起の導入による計算結果の改善}

式(3)の電流密度 $J$ に実験時の波形を周期的に与えながら, 連立 微分方程式(1)〜(3)を解いた. 解法は以下の通りである.

未知数 $n_{j}(j=p, q, r, s), n_{e}, T_{e}$ に任意の初期值を与えて, Runge-Kutta-Gill 法によって，一定時間ステップ後の解を，逐 次求める. 最初, 解は完全な周期性を示さないが, 電流の数サイ クル後, 解は収束し, 引き続く 2 サイクルの解が一致する.この 時, 自己矛盾のない初期值が得られたと判断し, その後の電流休 止期間中の共鳴準位密度から式(4)によって共鳴線の減衰曲線を計 算した。

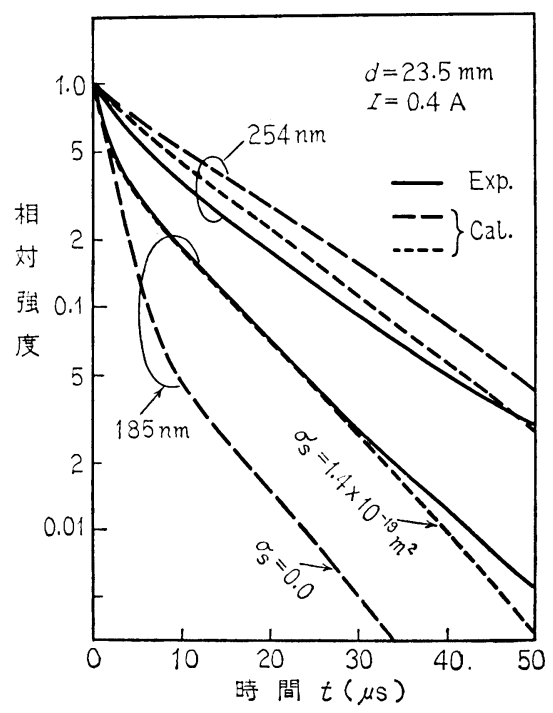

图 5 共鳴線減衰曲線の测定結果之計算結果の比較

図 5 に内径 $23.5 \mathrm{~mm}, I=0.4 \mathrm{~A}$ の場合の実験值（厼線）と計 算結果を比較して示す. 最初, 励起断面積のデータが見当たらな かった, 水銀 $6{ }^{3} \mathrm{P}$ 各準位から $6{ }^{1} \mathrm{P}_{1}$ への階段状励起を省略して計 算した. 結果は図 5 の破線に示すように, $185 \mathrm{~nm}$ の減哀が大き く, 電流停止後, $10 \mu \mathrm{s}$ 以降, 実験值の $1 / 4$ 程度になった。 これ は, 電流停止後 5〜 50 $\mu \mathrm{s}$ の期問においても, 図 4 に示したよう に電子温度が0.8 0.5 eV を保っている結果, 基底状態 $6{ }^{1} \mathrm{~S}_{0}$ か $56{ }^{1} \mathrm{P}_{1}$ への直接励起（しきい值 $6.7 \mathrm{eV}$ ) に対して, 階段状励起 (同1.3〜2.0 eV) が大きな役割を占めるためと考えられる.

次に, 階段状励起の断面積を適当に与えたところ, 四 5 の点線 のように $185 \mathrm{~nm}$ の減衰曲線を実測值と一致させることができ た.な拈，階段状励起の断面積の関数形は本解析に用いた $6{ }^{1} \mathrm{~S}^{0} \rightarrow$

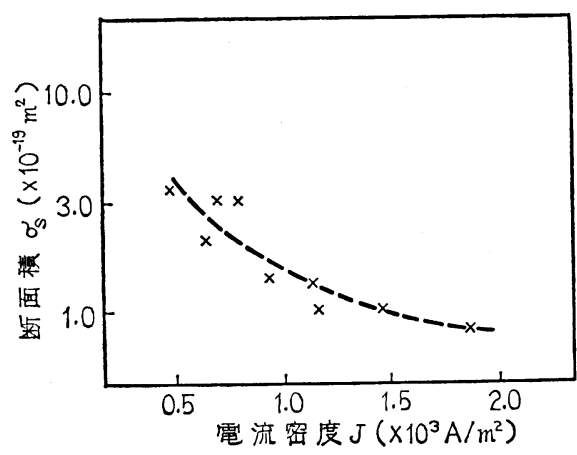

图 6 階段状励起の断面積 $\sigma_{s}$ 之電流密度 $J$ の関俰 
$6{ }^{3} \mathrm{P}_{2}$ のそれと相似でそれぞれ $1.56,2.13,2.33 \mathrm{eV}$ にピークを 持つものとし，その絶対值は下位準位によらないと仮定した．以 上の仮定のもとで図 5 の点線を与える階段状励起の断面積のピー ク值は $1.4 \times 10^{-19} \mathrm{~m}^{2}$ であった.

管径, 放電電流を変えて同様の方法で階段状励起の断面積 $\sigma_{8}$ を 求めると, 図 6 に示すように実験条件に依存しないはずの $\sigma_{s}$ が 電流密度の增加とともに減少した. 蛍光ランプ放電では, 電子ェ ネルギー分布はマクスウェル分布でなく, 放電条件によってその 関数形を変えることが理論的にわかっている ${ }^{15)}$. 図6の結果はこ のことを実訨したものであり，電子ェネルギー分布をマクスウェ ル分布に固定したため，一定であるべき $\sigma_{s}$ が見かけ上，電流密 度に依存したと解釈できる。

\section{2 非マクスウェル効果の見皘もり}

低圧水銀一希ガス放電中の電子エネルギー分布は, 非弾性衝突 の影響で ‘水銀の最低励起エネルギー $(4.7 \mathrm{eV})$ 以上のエネルギ 一を持つ電子の数が, 同じ平均ェネルギーを持つマクスウェル分 布より少なくなっていることが知られている(15)16)，これによっ て，たとえば6.7 eV のしきい值を持つ水銀基底状態から $6{ }^{1} \mathrm{P}_{1}$ 準 位への励起速度係数 $C_{g s}$ は, マクスウェル分布を仮定した計算で は，大きく見積もり過ぎになる，そこで非マクスウェル分布を導 入した場合の， $C_{g s}$ およびその時の $\sigma_{s}$ を $185 \mathrm{~nm}$ の放射パワ 一の計算值と実測值の比較によって推定した.

内径 $23.5 \mathrm{~mm}$ の放電管を放電電流 $I=0.4 \mathrm{~A}$ で直流点灯したと きの $254 \mathrm{~nm}, 185 \mathrm{~nm}$ の放射パワーを第 2 章の解析モデルで計算 した (解法は第 5 章参照).一方, Denneman $5^{17)}$ は, 内径 $24 \mathrm{~m}$ $\mathrm{m}$ の放電管を交流点灯して放射効率を報告している.この放射効 率および陽光柱電位傾度の実测值から, 力率を 1.0 として, 直流 点灯に相当する放射パワーを求め, われわれの計算結果と比較し た. その結果, $254 \mathrm{~nm}$ は，おおむね夷測值と一致するが， 185 $\mathrm{nm}$ の計算值は実測值の約 2 倍になることがわかった.

これは，マクスウェル分布を仮定しているため，直接励起 6 ${ }^{1} \mathrm{~S}_{0} \rightarrow 6{ }^{1} \mathrm{P}_{1}$ の 速度係数 $C_{g s}$ が大きくなり過ぎることに 原因があ る. $185 \mathrm{~nm}$ の放射パワーを実測值と一致させるには， $C_{g s}$ をマ クスウェル分布の場合の 0.4 倍程度にする必要があった。なお, $C_{g s}$ を変化させると同時に, 階段状励起の断面積 $\sigma_{s}$ も $185 \mathrm{~nm}$ の 減衰曲線が実験值と一致するように变化させた． $C_{g 8}$ を0.4倍し

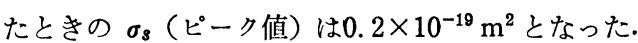

実際には, $6{ }^{3} \mathrm{P}$ 各準位の密度も非マクスウェル分布の影響で, 今回の計算結果よりやや少ないと考光られるので， $\sigma_{s}$ は $0.2 \sim$ $1.4 \times^{-19} \mathrm{~m}^{2}$ の間にあると推定できる. なお，最近 $\sigma_{s}=0.6 \times 10^{-1^{9}}$ （ピーク值）との報告がある ${ }^{18)}$.

\section{5. 非マクスウェル分布の導入}

\section{1 分 布 モ デル}

電子のエネルギー分布はボルツマン方程式解析によって理論的 に得られる. しかし, この方程式は非線形の微積分方程式で, 速 度方程式(1)，(2)と連立して解くのは容易ではない(1920)。 これに代 わるものとして提案されたのが 2 電子群モデル $(2-\mathrm{EGM})^{4) 21)}$ ある.このモデルでは，電子ェネルギー分布を水銀の最低励起エ

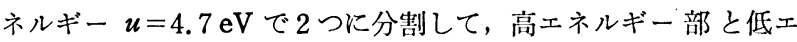
ネルギー部を, それぞれ異なる実効的な電子温度 $T_{b}$ と $T_{t}$ を持 つ2つのマクスウェル分布で以下のように表現する.

$f(u)=\left\{\quad 2 \pi\left(\pi k T_{b}\right)^{-3 / 2} u^{1 / 2} \exp \left(-u / k T_{b}\right) \underline{a} u \leq 4.7: \mathrm{eV}\right.$

$$
\begin{aligned}
& \text { \S. } 2 \pi\left(\pi k T_{t}\right)^{-3 / 2} u^{1 / 2} \exp \left(-u / k T_{t}\right) \quad u>4.7 \mathrm{eV} \\
& S=\left(T_{t} / T_{b}\right)^{3 / 2} \exp \left(4.7 / k T_{t}-4.7 / k T_{b}\right) \cdots \cdots \cdots \cdots(8)
\end{aligned}
$$

ここで， $T_{b}, T_{t}$ はそれぞれ低ェネルギー（bulk）部，高ェネ ルギー（tail）部の実効的電子温度, $S$ は $u=4.7 \mathrm{eV}$ で分布を連 続化するための係数である.

$T_{b}, T_{t}$ は原子と電子の衝突のほか，電子どうしのクーロン相 互作用で決まる．そのバランス式はマクスウェル分布の場合（式 (3)）よりも, 相当複雑になる. 2-EGM では, 電子密度 $n_{e}$, 励 起準位密度 $n_{j}$, 電子温度 $T_{b}\left(=T_{e}\right)$ 飞実測值を与之, 定常放 電 $(d / d t=0)$ に関する $T_{t}$ のバランス式だけを解いている.

われわれは，実測に手間のかかるプラズマメータは入力条件と して必要としないようなモデルの構築を目指した。 そして, 新し いアプローチとして速度方程式(1)〜(3)をそのまま活かす一方，低 エネルギー部の実效的温度 $T_{b}$ と高エネルギ一部の実効的温度 $T_{t}$ の関係を

$$
T_{t}=r_{T} T_{b}
$$

と簡略化して，係数 $r_{T}$ だけを実験的に決めることにした。ここ で, $r_{T}=1$ のとき, 分布(8)はマクスウェル分布に一致する. 高エ ネルギー電子が欠乏した営光ランプの放電では, 電子ェネルギー 分布は $0<r_{T}<1$ であるような 2 温度近似で表現できる.

2 温度近似したェネルギー分布(8)のもとで，しきい值が $4.7 \mathrm{eV}$ 以上の非弾性衝突の速度係数 $C^{\prime}{ }_{i j}$ は温度 $T_{e}$ のマクスウェル分 布の速度係数 $C_{i j}\left(T_{e}\right)$ を用いて，

$$
C^{\prime}{ }_{i j}=S C_{i j}\left(T_{t}\right)
$$

と書ける. しきい值が $4.7 \mathrm{eV}$ 以下の非弾性衝突および弾性衝突 については低ェネルギー電子だけが支配的になるので， $T_{e}$ を $T_{b}$ で置き換觉れば, 近似的にはマクスウェル分布の速度係数, 衝突 頻度がそのまま使觉る. 結局, 解析モデル(1) (3)自体は変更する ことわく，非マクスウェル分布を導入できた。

なお，計算には図 1 に示した諸過程のほか, 水銀 $6{ }^{3} \mathrm{P}$ 準位に ある原子どうしの衝突による電離 ${ }^{22}$ を新たに導入した。

\section{2 電子エネルギー分布の推定}

上記のモデルを直流放電に適用して，係数 $r_{T}$ を決定する方法 を検討した，直流放電にお注る解の求め方は以下の通りである. 式(3)の電流密度 $J$ に一定值を与兄, 任意の初期値から出発して, 一定時間ステップ後の解を求めていく. 最初, 解は時間的に変化 するが，次第に一定值に近づく，十分，収束したときの值を直流 放電の解として採用した.

まず， $r_{\boldsymbol{T}}$ に 0.4〜0.6の值を与えて，モデル式(1)〜(3)，(9)の解 および式(4)〜(6)から得られる放電パラメータの变化を観察した.

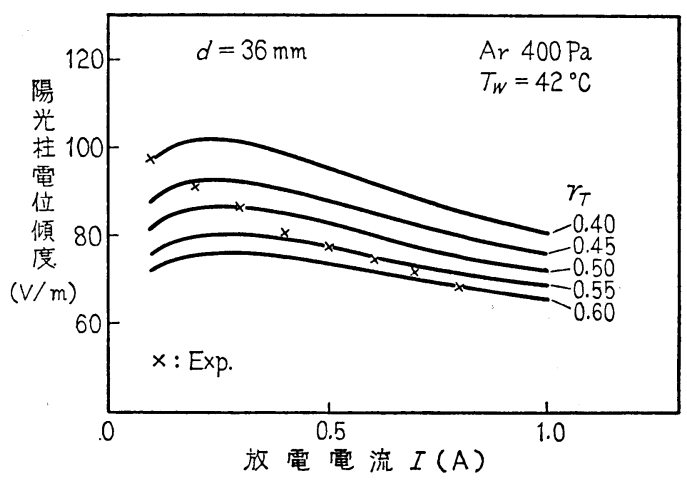

図 7 保数 $r_{T}$ を变えた奄位㑯度 $E$ の計算結果 (×印は文献(7)による実測値) 

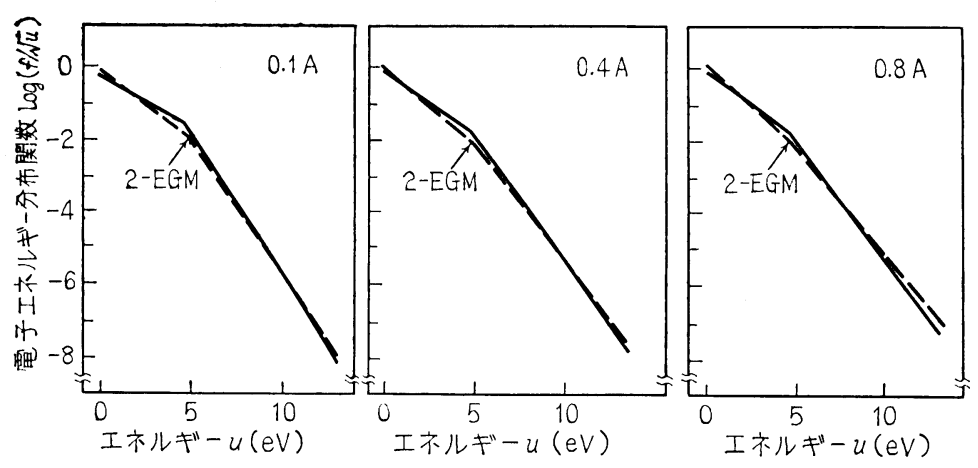

図 $8 T_{b}, T_{t}$ で代表した電子ェネルギー分布 (一) と2-EGM ( …) の 比較 $\left(d=36 \mathrm{~mm}, T_{w}=42^{\circ} \mathrm{C}, \operatorname{Ar} 400 \mathrm{~Pa}\right)$

その結果, 陽光柱の電位傾度 $E$ と $r_{T}$ との間によい相関があるこ とを見出した。图 7 に管内径 $36 \mathrm{~mm}$, 放電電流 $I=0.1 \sim 0.8 \mathrm{~A}$ について, 計算值と実測㯰 ${ }^{7}$ を示与. 陽光柱電位傾度 $E$ は $r_{T}=1$ （マクスウェル分布）のとき，実測值よりも25４5\%低く得られ た.一方, 高エネルギー部の電子数が欠乏した分布 $r_{T}<1$ を与学る と, 各電流值について， $r_{T}$ のある值で $E$ は実測值と一致する。 電流が増加すると，Eの計算值を実測值と一致させる $r_{T}$ は 1 に 近づく.これは, 電流密度が増加するに従って, 電子ェネルギー 分布がマクスウェル分布に近づくことを示している.

図 8 に $I=0.1 ， 0.4 ， 0.8$ A について分布関数(8)をプロッ卜 し，2-EGM の結果 ${ }^{21)}$ と比較した. マクスウェル分布におけるモ デルに式(9)を追加しただけだが，2-EGM の結果と良く一致する 結果を得た. 未知の係数 $r_{T}$ は，比較的容易に測定できる陽光性 の電位傾度 $E$ から決定できるので, 本研究によるモデルは放電シ ミュレーションモデルとして実用性が高い. 時間的に変化する放 電に適用できるのも利点である.

\section{3 シミュレーションモデルへの展開}

以上のモデルを放電シミュレーションに利用するためには，任 意の電流值，放電管径に適用できる必要がある，そこで，電子密

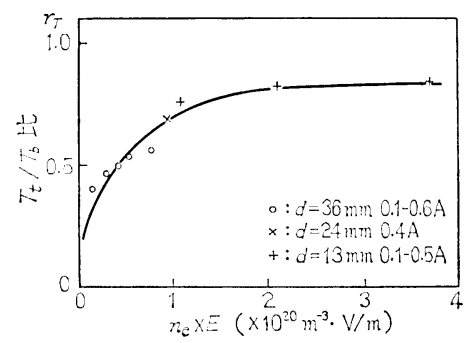

图 9 俰数 $r_{T}$ の関数形

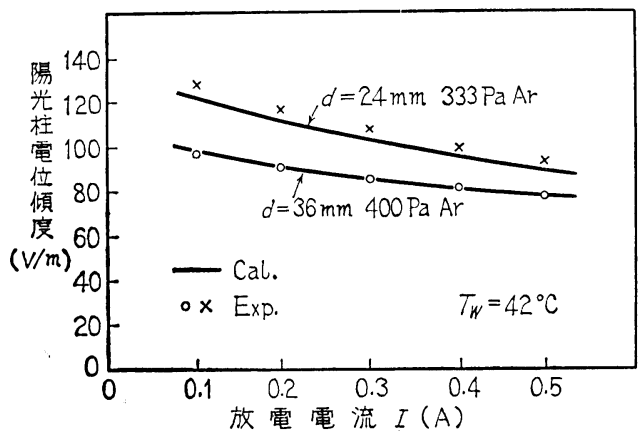

图 10 陽光柱の電位傾度Eのシミ $\mathrm{x}$ レー ション結果と㚻測值の比較
度 $n_{e}$, 陽光柱電位傾度 $E$ と $r_{T}$ の関係を調べてみた。電 子ェネルギー分布の関数形は $n_{e} お$ おび $E$ に大きく依存 すると考学られるので， $E$ 実测值から $r_{T}$ を決めて， $n_{e}$ (計算值) $\times E$ に対して $r_{T}$ をプロットすると図 9 の ように一本の曲線で代表できることがわかった，な挔図 9 の $r_{T}$ 管内径 $24 \mathrm{~mm}^{7}, 13 \mathrm{~m} \mathrm{~m}^{23)}$ について求めた ものも含を.

この曲線を

$$
r_{T}=r_{T}\left(n_{e} \times E\right)
$$

と経験的関数で表した．この式(11)による值を式(9)に代入 して，陽光柱のシミュレーション式とした。

図 10 に内径 $36 \mathrm{~mm}, 24 \mathrm{~mm}$ の陽光柱電位傾度 $E$ を 垶算した結果を示す. $36 \mathrm{~mm}$ 管の実测值は文献》から そった. $24 \mathrm{~mm}$ 管については, 第 6 章で述べるプローブ電極付の 放電管で測定した，本研究のシミュレーションモデルは管内径， 放電電流を变光ても，成り立つことがわかる。

\section{6. 共鳴線放射パワーの測定とシミュレーションとの 比較}

\section{1 共鳴線の放射強度の測定}

管内径 $24 \mathrm{~mm}$ の石英製放需管を直流で点灯して，水銀の両共 鳴線の相対放射強度を測定した．紫外線は第 3 章の分光装䍜で測 定し，信号は時定数の大きなアンプで增幅した．放電管には図 11 に示与上うに 4 本のプローブ電極を設置した。 このうち外側

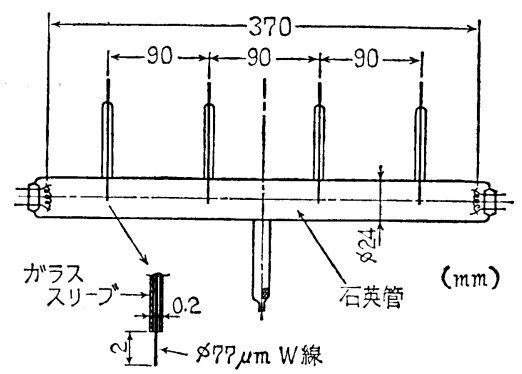

图 11 相放対射效害の測定に用いた プロープ電極付放讨管

の 2 本の浮遊電位を入力インピーダンス $1 \mathrm{M} \Omega$ 差動電圧計で測 定し，测定值を放電電流值に乘じて陽光柱電力を㨁読した。 な お，プローブ電極には外径77 $\mu \mathrm{m}$ のタングステン線を用い，放電 管軸上に設滥した先端部の $2 \mathrm{~mm}$ 以外はガラススリーブで絶縁し た，放電管本体は $70^{\circ} \mathrm{C}$ 一定の需四気中に保つ一方，最冷点温度 （中央下部の枝管外壁）の温度を $20 \sim 60^{\circ} \mathrm{C}$ の範团で変えて 水 銀 蒸気压を制御した。

\section{2 シミュレーションとの比較}

図 12 に陽光柱電力 $40 \mathrm{~W} / \mathrm{m}$ のときの水銀 $254 \mathrm{~nm}, 185 \mathrm{~nm}$ の放 射パワーの最冷点温度依存性を示す. 絶刘值は $42^{\circ} \mathrm{C}$ で文献值 ${ }^{17)}$ によって校正した．同時にシミュレーションモデルによる計算結 果を実線で示した. $185 \mathrm{~nm}$ の低温侧で，実测值との差が大きくな る傾向があるが，実測值をほぼ再現できるモデルになっている.

放射パワーの最冷点温度依存性が実測と一致しない原因の一つ は, $T_{b}$ との比 $r_{T}$ を与兄る関数が，水銀蒸気圧によって変化す るためと考兄れる。これを改善するためには，異なる水銀蒸気 压のもとで， $r_{T}$ を個々に実験的に決めればよいまた，ボルッ マン方程式を利用して, 電子ェネルギー分布から直接 $r_{\boldsymbol{T}}$ を求 


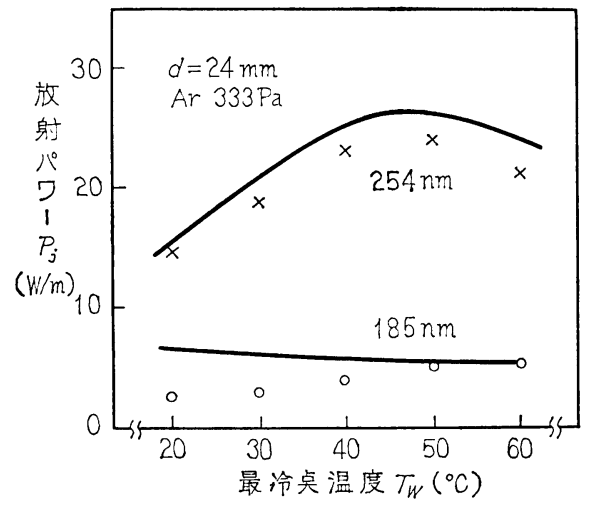

図 12 水銀共鳴放射の放射パワー ( $\mathrm{O}, \times$ : 测定値, 一計 筑值, 陽光柱電力 $40 \mathrm{~W} / \mathrm{m}$ )

め, 実験に頼らずにその閔数形を決めることも可能と考えられる。

\section{7.む す び}

水銀共鳴線の観測結果から低圧水銀一希ガス放電の解析を進 め，放電陽光柱の時間的変化を記述できるシミュレーションモデ ルに到達した．本研究のモデルでは，陽光柱の電位傾度に実测值 を与える必要がある．実験データの不足から，今のところ限られ たガス压力の組み合わせにしか適用できない，ガス圧力が異なる 場合の電子ェネルギー分布の変化を考虑することによって, 広い 条件下の放電のシミュレーションが可能となる. 電子ェネルギー 分布関数の決定方法としては, ボルッマン方程式解析のほか, 静 電プローブによる実測を検討している.

また，本研究ではアフターグローおよび直流放電にモデルを適 用した結果について述べた. 交流放電についても, 本研究に示し たモデルによって，陽光柱の電気的特性および共鳴線の放射パワ 一のシミュレーションが可能である ${ }^{24)}$. その結果については次の 機会に報告する予定である.

\section{参 考 文 献}

(1) Kenty' C.: Production of 2537 Radiation and the Role of Metastable Atoms in an Argon-Mercury Discharge, J. Appl. Phys. 21-12 (1950) 1309 1318

(2) Waymouth, J.F. and Bitter, F.: Analysis of the Plasma of Fluorescent Lamps, J. Appl. Phys. 27-2 (1956) 122 $\sim 131$

(3) Cayless, M. A : Theory of the Positive Column in Mercury Rare-Gas Discharges, Brit. J. Appl. Phys. 14-12 (1963) $863 \sim 869$

(4) Vriens, L.: Energy Balance in Low-Pressure Gas Discharge, J. Appl. Phys. 44-9 (1973) 3980 3989

(5) Polman, J., van der Werf, J. E. and Drop, P. C.: Nonlinear Effects in the Positive Column of a Strongly Modulated Mercury-Rare Gas Discharge, J. Phys. D: Appl. Phys. 5-2 (1972) 266 276

(6) Polman, J. and Drop, P. C.: Electron Temperature and $\mathrm{Hg}\left(6{ }^{3} \mathrm{P}\right)$ Atom Density Decay in a Mercry-Rare-Gas Afterglow, J. Appl. Phys. 43-4 (1972) 1577 1580

(7) Verweij, W.: Probe Measurements ane Determination of Electron Mobility in the Positive Column of LowPressure Mercury-Argon Discharges, Philips Res Rep. Suppl. (1961)
(8) Easley, M. A.: Probe Technique for the Measurement of Electron Temperature, J. Appl. Phys. 22-5 (1951) $590 \sim 593$

(9) Koedam, M. and Kruithof, A. A.: Transmission of the Visible Mercury Triplet by the Low Pressure MercuryArgon Discharge; Concentration of the $6{ }^{3} \mathrm{P}$ States, Physica 28-1 (1962) 80 100

(10) Wani, K.: Stepwise Excitation of the $\mathrm{Hg} 6{ }^{1} \mathrm{P}_{1}$ Level in the Afterglow of a Low-Pressure Hg-Ar Discharge, J. Appl. Phys. 58-8 (1985) 2968 2974

(11) 和迩浩一：低圧 $\mathrm{Hg}-\mathrm{Ar}$ 放電に括ける $\mathrm{Hg} 6{ }^{1} \mathrm{P}_{1}$ 準位の励 起機構, 照学全大 (昭59) 4

(12) Holstein, T.: Imprisonment of Resonance Radiation in Gases. II, Phys. Rev. 83-6 (1951) 1159 1168

(13) Nishimura, Y. and Fujimoto, T.: $\lambda=2537$ Å Line from a Low-Pressure Mercury Discharge Lamp Emission Profile and Line Absorption by a Gas Containing a Mercury Vapor, Appl. Phys. B 38 (1985) 91 98

(14) 奥野, 和迩, 宮本：低圧 $\mathrm{Hg}-\mathrm{Ar}$ 放電に打ける紫外線の減 衰照学全大（昭58） 7

(15) Winkler, R. B., Wilhelm, J. and Winkler, R.: Analysis of the Kinetic Properties and the Energy Budget of the Electron in the Ar-Hg Glow Discharge Plasma at Varying Partial Pressures and Discharge Currents, Beitr. Plasmaphys. 23-1 (1983) 25 40

(16) Uvarov, F. A. and Fabrikant, V. A.: The Absolute Concentration of Excited Atoms in the Positive Column of a Mercury Discharge, Opt. Spectr. 18-5 (1965) 433

(17) Denneman, J. W., de Groot, J. J., Jack, A. G. and Ligthart, F. A. S.: Insights into the $26 \mathrm{~mm}$ Diameter Fluorescent Lamp, J. Illum. Engng. Soc. 10-1 (1980) 2 7

(18) Post, H. A., : The Absolute $\mathrm{Hg} 6{ }^{1} \mathrm{P}_{1}$ Direct Electron Impact Excitation Cross Section Determined in a Low Pressure Hg Discharge, J. Phys. B: At. Mol. Phys., 17-15 (1984) 3193 3208

(19) Winkler, R. B., Wilhelm, J. and Winkler, R.: Kinetics of the Ar-Hg Plasma of Fluorescent Lamp Discharges I, Ann. der Phys. 7. Folge, 40-2/3 (1983) 90 118

(20) Winkler, R. B., Wilhelm, J. and Winkler, R.: Kinetics of the Ar-Hg Plasma of Fluorescent Lamp Discharges II, Ann. der Phys. 7. Folge, 40-2/3 (1983) 119 139

(21) Ligthart, F. A. S., Keijser, R. A. J.: Two-Electron Group Model and Electron Energy Balance in LowPressure Gas Discharge, J. Appl. Phys. 51-10 (1980) 5295 5299

(22) Vriens, L., Keijser, R. A. J. and Ligthart, F. A. S. : Ionization Processes in the Positive Column of the Low Pressure Hg-Ar Discharge, J. Appl. Phys. 49-7(1978) $3807 \sim 3813$

(23) Zhu. S. L. and Zhang, B. H.: Positive Column Characteristics of Small Diameter Fluorescent Lamps, 3rd International Symposium on the Science and Technology of Light Sources, (1983) 46

(24) 和迩浩一：低圧水銀一希ガス放電モデルの蛍光ランプシミ ュレーションへの応用, 照学全大 (昭61) 4

（受付1986年 9 月10日） 